\title{
The Influence of Industrial Policy on Innovation in Startup Enterprises: An Empirical Study Based on China's GEM Listed Companies
}

\author{
Fang Wang ${ }^{1}$ and Deyong Zhu $\mathbb{D}^{2}$ \\ ${ }^{1}$ School of Economics and Management, Wuhan University, Wuhan 430072, China \\ ${ }^{2}$ School of Tourism and Hospitality Management, Wuhan City Polytechnic, Wuhan 430072, China \\ Correspondence should be addressed to Deyong Zhu; zhudeyong@whcp.edu.cn
}

Received 4 August 2021; Revised 14 October 2021; Accepted 16 October 2021; Published 29 October 2021

Academic Editor: Sameh S. Askar

Copyright (c) 2021 Fang Wang and Deyong Zhu. This is an open access article distributed under the Creative Commons Attribution License, which permits unrestricted use, distribution, and reproduction in any medium, provided the original work is properly cited.

\begin{abstract}
This study uses China's Growth Enterprises Market (GEM) listed companies from 2011 to 2017 as samples to examine the impact of industrial policies on innovation in startups from three dimensions, namely, selective industrial policies, government subsidies, and financial support. The results show that selective industrial policies have no effect on the innovation output of startups. Financial support can significantly promote the innovation output of entrepreneurial enterprises; structural differences exist in the impact of government subsidies on the innovation of entrepreneurial enterprises. The influence of industrial policy on the innovation of entrepreneurial enterprises depends on the research and development intensity of enterprises, the level of regional economic development, the leadership structure of enterprises, and other factors. This study's findings have significant practical significance for the implementation of a national innovation-driven development strategy and to guide industrial policies that better promote enterprise innovation.
\end{abstract}

\section{Introduction}

The term "industrial policy" was put forward by the representative of Japan's Ministry of Trade and Industry at the Organization for Economic Cooperation and Development (OECD) conference in the 1970s. At the time, Japan's economy was advancing rapidly, creating a "post-war miracle." Industrial policy played an important role in this process and has attracted widespread attention ever since. China has gradually developed systematic industrial policies since the late 1980s, and its rapid economic growth since 1978 has benefited from the implementation of various industrial policies [1]. Since the beginning of the 21st century, the Chinese government has strengthened its intervention in the microeconomy and continued to enhance the implementation of industrial policies. Currently, China has many industrial policies and industrial planning documents that cover almost all industries, with their influence reaching all aspects of the national economy. Entering a period of economic "new normal" (returning to a normal state after a period of abnormality), industrial policies are still required. This is primarily because the technological innovation and industrial upgrade for the promotion of economic development require the efforts of entrepreneurs as well as government assistance to solve difficult externalities and coordinate the corresponding soft and hard infrastructure [2].

Between 2016 and 2020, with the progress of the information age and the deepening of China's economic transformation, the contradiction accumulated by extensive economic growth driven by factor input and investment has become increasingly prominent and has gradually become the bottleneck of sustained economic development [3]. Economic growth is facing a critical stage of transformation from a factor-driven model to an innovation-driven model. The innovation efficiency of microsubjects is high, which is an important carrier of innovation activities [4]. Innovation is an inexhaustible driving force for the progress of 
microsubjects. Therefore, the promotion of enterprise innovation has become a focus of society. In the new period, small- and medium-sized enterprises (SMEs) have become an emerging driving force for the transformation and upgradation of China's industrial structure and innovationdriven development. They further influence the guiding effect of industrial policies on enterprise innovation and have become one of the key forces for China's industrial transformation and upgradation as well as the transformation of the mode of economic development.

A section of the literature on the impact of industrial policy on enterprise research and development (R\&D) innovation reveals the belief that industrial policy can promote enterprise $R \& D$ innovation. Choi et al. [5] believe that certain selective industrial policies directly increase corporate profits that companies can survive a small amount of innovative behavior, and their willingness to innovate will be reduced. Scholars who support industrial policy recognize that such policies promote enterprise $R \& D$ innovation, but hold different views on the mechanism of these policies' influence on enterprise $\mathrm{R} \& \mathrm{D}$ innovation [6]. Industrial policies can influence R\&D innovation through policy tools such as tax incentives, financial loans, and government subsidies. Many scholars have examined the impact of industrial policy tools such as government subsidies and tax incentives on $\mathrm{R} \& \mathrm{D}$ innovation, but the results are not consistent. Some scholars believe that government subsidies can promote enterprise $\mathrm{R} \& \mathrm{D}$ innovation. Yu [7] believes that, in the short term, government subsidies can promote enterprises' R\&D and innovation output. Scott [8] analyzed the data of American companies and found that government R\&D subsidies and corporate R\&D investment are positively correlated. Liu et al. [9] examined high-tech enterprises in Jiangsu Province and found that government subsidies for R\&D play a significant role in promoting R\&D expenditures, and private enterprises play a stronger role in promoting R\&D than their state-owned counterparts. Jin et al. [10] showed that receiving government subsidies improves private $R \& D$ investment and firm performance, that government $R \& D$ subsidies can stimulate corporate $R \& D$ investment, and that subsidies have no significant impact on innovation performance, while $\mathrm{R} \& \mathrm{D}$ investment has a positive impact. $\mathrm{Xu}$ et al. [11] found that government R\&D subsidies can stimulate corporate R\&D investment, and they have no significant impact on innovation performance, while $R \& D$ investment has a positive impact. In addition, environmental policies also affect the innovation efficiency of regions or companies $[12,13]$. Some scholars believe that government subsidies have a squeezing effect on enterprises' $\mathrm{R} \& \mathrm{D}$ and innovation. This is because these subsidies can directly increase the profits of enterprises and compensate for the losses of enterprises to a certain extent. Enterprises can obtain profits without innovation, which may lead to them reducing $\mathrm{R} \& \mathrm{D}$ innovation activity. Bound et al. [14] studied large- and medium-sized manufacturing companies in the United States and found that, with an increase in R\&D investment, the number of patents obtained by companies declined. Hall [15] believes that government subsidies can increase corporate profits to a certain extent, improve their survival even with low R\&D efforts, and reduce the enthusiasm of corporate $\mathrm{R} \& \mathrm{D}$, so that it has a crowding-out effect.

This paper details the influence mechanism of entrepreneurial innovation industrial policy and presents corresponding policy recommendations based on the research results to promote China's business enterprise innovation. The marginal contributions of this study are as follows:

(1) This study introduces the influence of government subsidy policy and financial support (FS) policy on enterprise innovation into the same research framework and further divides the former into science and technology special subsidies and nonscience and technology special subsidies. The research findings support the implementation of different types of industrial policies and improving the efficiency of policy implementation.

(2) This study provides new evidence based on entrepreneurial enterprises. In previous studies, most research has focused on mature large- and mediumsized enterprises as research samples for the sake of data availability and convenience. This study considers entrepreneurial enterprises as the empirical object and responds to the encouragement to entrepreneurial enterprises through the advocacy of "mass innovation and entrepreneurship" in the $13^{\text {th }}$ National Five-Year Plan and other documents.

This study examines the impact of industrial policies on enterprise R\&D innovation from three dimensions: selective industrial policy, government subsidies, and FS. It helps to further refine the impact of different industrial policies on enterprise $\mathrm{R} \& \mathrm{D}$ innovation and enrich the impact of industrial policy tools on this process. At the same time, industrial transformation and upgrading are inseparable from enterprise innovation. This study examines industrial policies from the perspective of microenterprises, tests whether industrial policies are based on enterprises, and provides an empirical basis for the formulation and improvement of industrial policies.

\section{Background and Hypotheses}

2.1. Background. Generally, industrial policy can be divided into "functional industrial policy" and "selective industrial policy." "Market-friendly" functional industrial policies create an environment for industrial development. More enterprises are allowed to enter the market, and "pre-support" (infrastructure construction, talent cultivation, etc.) influences enterprise behavior as a primary factor. Selective industrial policies provide "after-the-fact support" (subsidies, such as price and operating loss, tax incentives, etc.) to subsidize or protect specific enterprises. In the 21st century, the Chinese government has emphasized the key role of market mechanisms in resource allocation and has gradually paid more attention to the market-friendly "functional industrial policy." However, the history of China's planned economy system results in the continuation of the previous government's intervention regarding industrial policy. 
Meanwhile, China is still in the early stage of the transition from a "planned economy" to a "market economy." The healthy development of the social economy is inseparable from government intervention and guidance. Industrial policy is still dominated by "selective industrial policy," which remains strong. The characteristics of direct interventions have made the "selective industrial policy" more sophisticated.

Enterprise innovation is "an entrepreneurial combination of production factors or production conditions," which means "forming a new production function" to realize potential profits. Innovation is a collection of technological innovations in an enterprise. In the era of rapid innovation, innovation is the most important and likely way for a company to achieve sustainable prosperity. Contemporary economist Joseph Schumpeter proposed that a company's research, together with development and innovation, can not only stabilize its competitive advantage but also break through the inherent system to promote business progress. However, the importance of corporate innovation in social and economic development is unquestionable.

2.2. Hypotheses. Most of the existing literature posits that industrial policies have reduced financing constraints to a certain extent and promoted $\mathrm{R} \& \mathrm{D}$ investment $[16,17]$. However, some scholars are skeptical, and Li et al. [18] believe that companies with political connections will use support policies for rent seeking and will not increase investment in innovation. For Growth Enterprise Market (GEM) companies, the appropriate implementation of industrial policies will stimulate R\&D investment, which will lead to a "seed effect," an "induced effect," and even a "selfenhancing effect" on innovation [19]. Financial means and financial policies can effectively change the external economic environment of corporate innovation activities [20-24]; this is conducive to external financing and expansion of investment, which is the basic premise for enterprises carrying out innovation activities. Large enterprises may have the strength to bear the risks brought by the complexity, high investment, and uncertainty of innovation activities, while SMEs lack strength and resources, as well as face serious financing difficulties, high innovation costs, unsustainable scientific and technological innovation, and other practical problems [25].

Based on the above theoretical analysis, this study adopts "industrial policy-driven internal and external factors regulation-enterprise innovation output" as the main line to build the theoretical framework. According to the above analysis, industrial policies can positively stimulate enterprises' innovation output activities through guidance and support, as shown in Figure 1.

$\mathrm{H1}$ : selective industrial policy support can increase the level of innovation output of entrepreneurial enterprises.

\subsubsection{Government Subsidies and Enterprise Innovation} Output. Government subsidies are widely used by governments and research circles as an important method of guiding enterprise innovation. The FS provided by the government to enterprises tends to focus on the following two projects: the first is technology projects with strategic, high-risk, and frontier characteristics [26-28], such as cutting-edge technologies related to emerging industries, and basic R\&D projects, which are characterized by foundation, a long investment period, and high spillover. Such an investment can help solve the problems of promoting the progress of basic technology or breaking through common technical problems. Regardless of the kind of FS, its pertinence is strong, can better guide and support the development of specific industries or regions, and is a direct means of innovation stimulus.

Tax incentives are the government's care measure for taxed objects. Compared with FS, tax incentives involve the government transferring a portion of fiscal revenue to enterprises, focusing on the use of the market and enterprises' own power to stimulate the R\&D investment of enterprises indirectly, which is more inclusive. However, from the government's perspective, the effectiveness of the tax incentive policy can only be achieved when the innovation benefit brought by the tax incentive policy is higher than the reduced fiscal revenue [29].

Based on the above analysis, government subsidy policy plays a positive role in promoting enterprise innovation. At the same time, this paper believes that the special subsidy means of science and technology are more targeted at stimulating innovation output. Therefore, the following hypotheses are proposed:

$\mathrm{H} 2$ : government subsidies can increase the level of innovation output in startups.

H3: special subsidies for science and technology have a greater effect on innovation output in entrepreneurial enterprises than nontechnical special subsidies.

\subsubsection{Financial Support and Enterprise Innovation Output.} As an external incentive for enterprise innovation, FS has a positive impact on corporate innovation, mainly by improving the financing environment and playing a signal role. The role of FS is mainly realized by improving the financing environment faced by enterprises or helping them solve the innovation bottleneck of financing difficulty. Generally speaking, FS can be achieved through three aspects: banking, capital markets, and insurance markets [30], through lowinterest loans, loan guarantees, and capital market and venture capital market financing measures widely used in China, Japan, Germany, and the United States. FS plays an active role in promoting enterprise innovation. The release of positive signals helps reduce and avoid the information and transaction costs between enterprises and financial institutions and helps enterprises apply for loans [31-33]. FS can not only directly improve the financing environment and solve the capital bottleneck but also indirectly promote enterprise innovation by releasing signals.

In this study, low-interest loans were used as indicators of FS. Since it is difficult to obtain the data of targeted loans provided by state-owned banks or local governments in China, we referred to the treatment method of Aghion et al. [34] in their article "Industrial Policy and Competition" and 


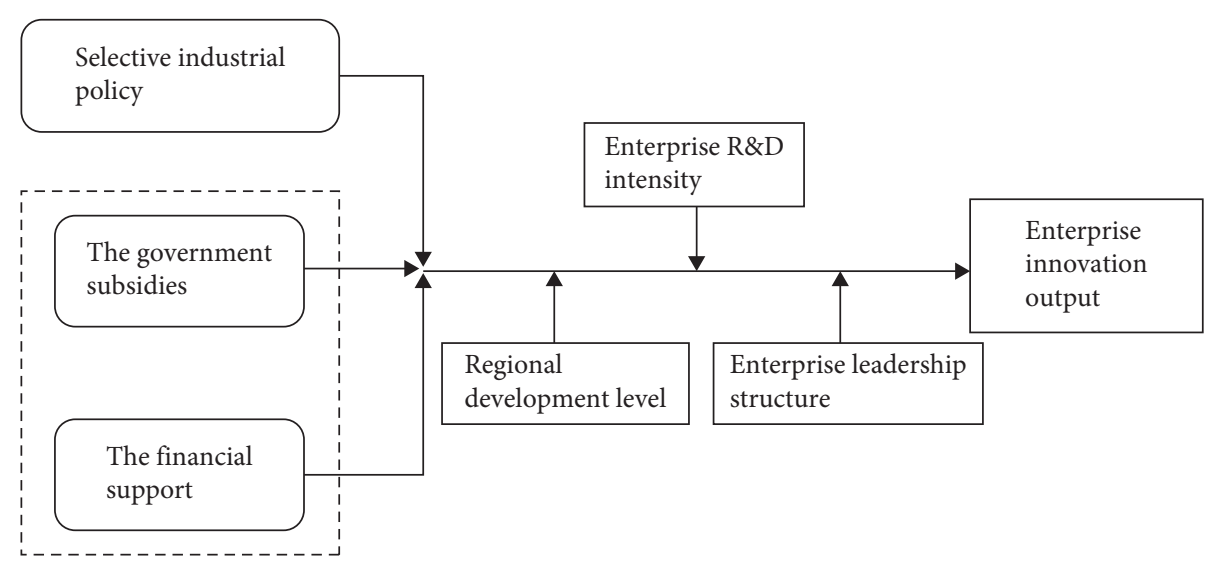

FIgURE 1: The path of industrial policy affecting enterprise innovation.

used the ratio of interest expenditure published by enterprises and current liabilities to form an alternative indicator of low-interest loans. Based on the above analysis, the following hypothesis is proposed:

H4: financial support can improve innovation output level in entrepreneurial enterprises.

\subsubsection{Adjustment of Policy Effects by Internal and External} Factors. Some scholars have researched the role of internal and external factors in regulating the effects of policies. At the enterprise level, most studies are on enterprise scale, property right nature $[23,35]$, or enterprise type [36, 37]. Since the research object of this paper is a GEM enterprise, the entrepreneurial enterprise is an SME, and the enterprise is small in scale. Next, in order to clarify whether the nature of the enterprise has research value among the GEM enterprises, this study adopts "whether the top ten shareholders have state-owned shares." The analysis of the two indicators of "the nature of equity" found that the research value was limited. Therefore, this was abandoned in favor of situational factors. The following three aspects are studied under the premise of basic research:

First, analysis of the source of R\&D funding in various countries revealed that, among Chinese, Japanese, American, and German societies, the R\&D expenditure of enterprises accounted for $74 \%, 77 \%, 62 \%$, and $66 \%$ of R\&D expenditure, respectively, and remained the core support for the R\&D expenditures of various countries. Many scholars have confirmed the important role of enterprise $R \& D$ intensity in innovation. For example, Benat [38] found that enterprise $\mathrm{R} \& \mathrm{D}$ activities bring innovation growth to enterprises. Research on the influencing factors of enterprise innovation performance [39] also found that innovative resources, including the strength of enterprises' $R \& D$, help enterprises to introduce advanced R\&D equipment, advanced technology, and scientific and technological talents, and have a significant impact on the innovation output of enterprises.

Therefore, this paper refers to the existing research and finds that the R\&D intensity of the enterprise itself is included in the scope of examination, and its regulatory effect on the effect of industrial policy is examined. The following hypothesis is proposed:

H5: the promotion effect of industrial policies on the innovation output of entrepreneurial enterprises is stronger in enterprises with high $\mathrm{R} \& \mathrm{D}$ intensity than those with low R\&D intensity.

Second, examining China's R\&D investment revealed that local financial science and technology investment has gradually increased and overtaken that of central government. This result is a normal reaction of the central government's moderate decentralization, which inevitably increases regional development differences. The influence of factors on the innovation of enterprises in local areas has gradually attracted the attention of scholars. For example, Hao et al. [40] studied the impact mechanism of regional factors on entrepreneurial innovation and found that regional factors significantly affect the innovation performance of enterprises in the region, calling it "the regional gap effect of entrepreneurial innovation performance.” Kong [41] used panel data from seven provinces municipalities, and autonomous regions since 2000 and found that the impact of tax incentives on technological innovation differs in different regions. The author believes that there are more factors that offset the influence of tax incentives on technological innovation in regions with higher or lower degrees of economic development.

This study argues that the level of regional economic development may indeed have an impact on policy outcomes. In economically developed areas, the positive impacts of government subsidies and FS mean they may be better absorbed, the enthusiasm for technological innovation is higher, and the external effects are timelier. Therefore, the following hypothesis is proposed:

H6: the promotion of industrial policies to entrepreneurial innovation is more pronounced in developed regions than in economically backward regions.

Third, regarding the governance structure of entrepreneurial enterprises, Peng's [42] study of the first batch of listed companies on the GEM as the research object revealed that the family-owned governance model of entrepreneurial enterprises is more important, and that ownership and management rights are unified. The phenomenon of "single 
shares," whereby the Chairman is also the General Manager, exists so that "the two powers are one." In fact, the influence of the leadership structure of the board of directors on enterprises has long been the focus of scholars, but the research conclusions differ. Zahra et al. [43] found that the separation of the two positions is positively related to the level of enterprise innovation in the study of medium-sized enterprises. Wang [44] and $\mathrm{Xu}$ [45] also found that their separation has a positive impact on corporate technological innovation. Some scholars have reached the opposite conclusion. For example, Brickley et al. [46] found that, in most enterprises, the cost of separation of jobs is greater than the benefits.

There is limited research on corporate innovation from the perspective of corporate governance, but the leadership characteristics of the board can indeed affect the innovation activities of enterprises, but it is not the same in different regions and enterprises. This study explores whether the innovation activities of entrepreneurial enterprises are significantly affected by leadership structure is explored in this study. Therefore, in the specific operation, the group's internal "Chairman and General Manager" is used as a surrogate index to conduct a group study. At the same time, the Herfindahl index of the top ten shareholders of the company is used as a surrogate indicator for the robustness test. Regarding the innovation activities of enterprises, it is assumed that although they can improve the efficiency of decision-making, the correctness of the decision is not guaranteed. When the two are positions are held separately, they can avoid the excessive concentration of power, overcome the rigidity of decision-making and cognitive limitations, and improve the correctness of innovation decisions, which may be more conducive to the innovative growth of the company. The hypothesis is as follows:

H7: when the structure of corporate leadership is dispersed, industrial policies have a more significant effect on the innovation of entrepreneurial enterprises.

\section{Data and Model}

3.1. Data. The sample comprised 498 GEM companies listed in the Shenzhen Stock Exchange from 2011 to 2017. Data of GEM companies with stock codes 300001-300498 were adopted to eliminate companies with serious data deficiencies. Finally, the research samples obtained were nonequilibrium panel data, with a total of 2,185 observed values.

In this study, the information on selective industrial policy mainly comes from the Five-Year Plan issued by the Chinese government. As it is difficult to measure, the practices of $\mathrm{Yu}$ [23] and $\mathrm{Li}$ [18] are referenced to study industrial policies and expressed industrial policies by defining dummy variables at the industry level. In this study, we divided industrial policy into general encouragement policy and key encouragement policy.

The financial data of each company, as well as the basic calculation data of government subsidies and FS, come from the China Stock Market \& Accounting Research (CSMAR) database, the China Statistical Yearbook of Science and Technology (2006-2016), and the China Statistical Yearbook
(2006-2016), from which patent data were combined with the CSMAR database and the patent database of the National Intellectual Property Office of China.

The independent variables include selective industrial policy, government subsidy, and FS.

Regarding the specific operation, the analysis is divided into general incentives and key incentives for industrial policies according to the degree of industrial policy encouragement. Industries that are generally encouraged were selected from the documents of the $11^{\text {th }}$ and $12^{\text {th }}$ Five-Year Plans. If the $11^{\text {th }}$ and $12^{\text {th }}$ Five-Year Plans mentioned encouragement, support, key development, or vigorous development, they were considered as a general incentive industry, defined as the variable IP_ind1, and assigned a value of 1 , with the others assigned a value of 0 . If the $11^{\text {th }}$ and $12^{\text {th }}$ Five-Year Plans clearly mentioned key development or vigorous development, the industry was considered to be a key incentive industry, defined as the variable IP_ind 2 and assigned the value 1 , with the others assigned the value 0 , thus generating a new dummy variable.

Industrial policy at this level includes government subsidies and FS:

\section{(1) Government subsidy}

After studying the breakdown of government subsidies received by GEM companies, this study intended to focus on whether the special subsidies for science and technology play a key role in the innovation output of enterprises and are more targeted. Finally, we compare the government subsidy income obtained by the company with the number of employees and then use the logarithm to define the government subsidy indicators, which were divided into three categories: government total subsidy (Sub), technology special subsidy (Techsub), and non-technology special subsidies. (Ftechsub).

(2) Financial support

This study drew on the treatment of "Industry Policy and Competition" by Aghion et al. [34] to compare the ratio of interest expenditure to current liabilities to measure low-interest loan policy as a substitute for FS.

The dependent variable is the startup's innovative output. Regarding innovation output, there are two main measurement methods in the existing literature. One is the number of patent applications, the number of licenses, or the number of citations [47]; the second is the use of enterprise development or the number of improved new products [48]. This study used the number of patent applications of enterprises to measure enterprises' innovation output. The patent application year is used as the innovation output year of the enterprise. The patent application data come from the statistics of the CSMAR database and are defined as the variable patent.

With reference to the research of Yu [23]; combined with the actual research needs, when studying the actual impact of selective industrial policies on government subsidies and FS on the number of patent applications, we control important 
variables at the enterprise and regional levels. The specific variable definitions are listed in Table 1.

Table 2 presents the descriptive statistics for the main variables. From Table 2, the average number of patent applications (Patent) is 12.66, and the standard deviation is 24.3362. This shows that the number of patents between GEM companies differs greatly, and the level of innovation output is uneven. The average number of patents relative to mature companies is 57.2, and the level of innovation output of entrepreneurial enterprises needs to be improved. The average value of encouraging industrial policies is 0.8492 , indicating that $84.92 \%$ of the enterprises that participated in the patent application during the research period were in the range of industrial policy incentives in the broadest sense. The average value of the key encouraging industrial policies is 0.3761 , indicating that the key support of industrial policies is targeted to some extent, and $37.61 \%$ of GEM enterprises are in industries that are mainly encouraged by industrial policies. After comparing the number of employees with government subsidies and taking the natural logarithm, the average value is 8.9514, which is divided into science and technology special projects and nonscience and technology special projects. The average value is 7.4822 and 8.3309 , respectively, and the maximum and minimum values of each indicator vary greatly, indicating that, in terms of government subsidies, the types and intensity of subsidies received by each enterprise vary greatly. The standard deviation of FS policies is 2.3106 , with a maximum value of 26.3117 and a minimum value of 0 , indicating that the FS intensity of each enterprise varies greatly. The average $R \& D$ intensity (rde) is 0.069 , which means that, on average, the proportion of R\&D investment in the sample to operating income is $7 \%$, and the gap between high R\&D investment intensity and low $R \& D$ investment intensity is obvious. In terms of corporate governance structure, $45.5 \%$ of GEM enterprises have the situation in which the Chairman of the Board also serves as the General Manager. The mean value of the regional dummy variable is 0.3807 , indicating that approximately $38 \%$ of the sample companies are located in developed areas, such as Beijing, Shanghai, Guangzhou, and Shenzhen.

3.2. Model. In the empirical study, the patent application data of the dependent variable are discrete variables greater than or equal to 0 . According to the research characteristics and variable properties of this study, we refer to Woodridge's "Econometric Analysis of Cross Section and Panel Data." In this book, the counting data model is selected for analysis.

To test the impact of selective industrial policies on the innovation output of start-up enterprises, the following model was constructed:

$$
\text { Patent }_{i t}=\alpha+\beta_{1} \text { IP_ind } 1(\text { IP_ind } 2)+\beta_{2} \text { Control }_{\mathrm{it}}+\varepsilon_{\mathrm{it}} .
$$

In the formula, Patent is the number of patent applications of the company, IP_ind1 and IP_ind2 are the dummy variables of industrial policy incentives, which are generally to encourage industrial policies and key industrial policies, and $\beta$ represents the coefficient of each explanatory variable.

To test the impact of government subsidies on the innovation output (patent application) of entrepreneurial enterprises, it is further divided into technology subsidies (Techsub) and non-technical special subsidies (Ftechsub). The following model was built:

$$
\text { Patent }_{i t}=\alpha+\beta_{1} \operatorname{lnsub}_{\text {it }}\left(\text { lntechsub }_{\text {it }}, \operatorname{lnftechsub}_{\text {it }}\right)+\beta_{2} \text { Control }_{i t} .
$$

Among them, lnsub is the total amount of government subsidies in ten thousand yuan, which is expressed as a logarithm of the number of employees in the company in the current year. lntechsub is a special subsidy for science and technology, and lnftechsub is a special subsidy for nontechnical purposes. If $\mathrm{H} 4$ is established, $\beta 1$ is significantly positive when regression is performed with lntechsubit as an explanatory variable. To test the impact of FS on entrepreneurs' innovation output, the model is as follows:

$$
\text { Patent }_{\text {it }}=\alpha+\beta_{1} \mathrm{FS}_{\mathrm{it}}+\beta_{2} \text { Control }_{\mathrm{it}}+\varepsilon_{\mathrm{it}},
$$

where FS is financial support and is expressed as interest liabilities as a current liability [34], so the positive contribution of FS appears as a negative coefficient. Assuming that the coefficient of $\beta 1$ is significantly negative, when FS is strengthened, the number of patent applications of startup companies increases.

According to a detailed analysis of the results, the intensity of enterprise $R \& D$ is key to the role of industrial policies in innovation output. At the same time, we consider that both the government and enterprises are the two main players supporting China's technological innovation system, and their subjective initiative is the key. The most intuitive manifestation of this initiative is investment in $\mathrm{R} \& \mathrm{D}$ activities. The government relies on policy guidance and support, while the enterprise determines its own investment in $R \& D$, which leads to the intensity of corporate research on government policy, the effect of the regulation of this problem. Therefore, this study used the GEM as a sample to test H5. The models were constructed as follows:

$$
\begin{aligned}
\text { Patent }_{\mathrm{it}}= & \alpha+\beta_{1} \operatorname{lnsub}_{\mathrm{it}}\left(\operatorname{lntechsub}_{\mathrm{it}} \operatorname{lnftechsub}_{\mathrm{it}}\right) \\
& +\beta_{2} \operatorname{lnsub}_{\mathrm{it}}\left(\operatorname{lntechsub}_{\mathrm{it}}, \operatorname{lnftechsub}{ }_{\mathrm{it}}\right) * \mathrm{RDE}+\beta_{3} \mathrm{RDE} \\
& +\beta_{4} \text { Control }_{\mathrm{it}}+\varepsilon_{\mathrm{it}},
\end{aligned}
$$

$$
\text { Patent }_{\mathrm{it}}=\alpha+\beta_{1} \mathrm{FS}+\beta_{2} \mathrm{FS} * \mathrm{RDE}+\beta_{3} \mathrm{RDE}+\beta_{4} \operatorname{Control}_{\mathrm{it}}+\varepsilon_{\mathrm{it}} \text {. }
$$

According to regional characteristics and corporate leadership structure, specific indicators are used: the former was based on whether the headquarters of the company are located in the developed areas of Beijing, Shanghai, or Shenzhen, indicating the difference in the level of economic development of the region in which the enterprise is located. The latter study in this enterprise, whether the Chairman and the General Manager are concurrently responsible for 
TAвLE 1: Variable descriptive statistics.

\begin{tabular}{|c|c|c|}
\hline definition & Variables & Description \\
\hline \multicolumn{3}{|l|}{ Dependent variables } \\
\hline \multicolumn{3}{|l|}{ Independent variables } \\
\hline General incentive policy & IP_ind1 & $\begin{array}{l}\text { If the "Eleventh Five-Year Plan" and the "Twelfth Five-Year Plan" document mention } \\
\text { encouragement, support, key development, or vigorous development, it is considered as a } \\
\text { general incentive industry, defined as the variable IP_ind1, assigned the value 1, and the } \\
\text { other is } 0\end{array}$ \\
\hline Key incentives & IP_ind2 & $\begin{array}{l}\text { If the "Eleventh Five-Year Plan" and the "Twelfth Five-Year Plan" clearly mention the key } \\
\text { development or vigorous development, the industry is considered as the key incentive } \\
\text { industry, defined as the variable IP_ind } 2 \text { and assigned the value } 1 \text {, the other is } 0\end{array}$ \\
\hline Government subsidy policy & Sub & Total subsidy/total number of employees and take the logarithm \\
\hline $\begin{array}{l}\text { Special subsidies for science and } \\
\text { technology }\end{array}$ & Techsub & $\begin{array}{l}\text { Total amount of special subsidies for science and technology/total number of employees and } \\
\text { take the logarithm }\end{array}$ \\
\hline Non-tech special subsidy & Ftechsub & Total non-technical special subsidies/total number of employees and take the logarithm \\
\hline Financial support & FS & Interest expense/current liabilities \\
\hline \multicolumn{3}{|l|}{ Control variables } \\
\hline Environment system & IPO & The listing value after listing in 2012 is 1 , and the listing value in 2012 and the previous year is \\
\hline Business scale & & Logarithm of total assets \\
\hline Corporate cash flow & & Net cash flow from operating activities/total assets \\
\hline Asset-liability ratio & & Total liabilities/total assets \\
\hline Current ratio & $\mathrm{CR}$ & Current assets/currer \\
\hline Return on total assets & ROA & $\begin{array}{c}\text { Net profit/average balance of total assets }((\mathrm{end} \text { of assets total balance }+ \text { initial balance of } \\
\text { assets } / 2)\end{array}$ \\
\hline Business age & & The time interval from the date of establishment of the start-up to the statistical year \\
\hline Adjunct & Dual & The Chairman and general manager have a value of 1 , and the others are 0 \\
\hline R\&D intensity & $\mathrm{RDE}$ & $\mathrm{R} \& \mathrm{D}$ investment amount/operating income \\
\hline Regional dummy variable & Region & $\begin{array}{c}\text { The company's headquarters is located in Beijing, Shanghai, Guangzhou, Shenzhen, and the } \\
\text { value is } 1 \text {, otherwise } 0\end{array}$ \\
\hline Industry dummy variable & Industry & $\begin{array}{c}\text { The "2012 Industry Classification Guidelines" issued by the China Securities Regulatory } \\
\text { Commission was used to classify and statistic, and two dummy variables of C and I } \\
\text { categories were set }\end{array}$ \\
\hline Annual dummy variable & Yeard & There were seven dummies variables from 2011 to 2017 \\
\hline
\end{tabular}

TABle 2: Descriptive statistics of major variables.

\begin{tabular}{|c|c|c|c|c|c|c|}
\hline Variable & Symbol & Mean & Max & Min & Standard deviation & Observations \\
\hline Innovation output & Patent & 12.6586 & 377 & 0 & 24.3362 & 2188 \\
\hline General incentive policy & IP_ind1 & 0.8492 & 1 & 0 & 0.3580 & 2188 \\
\hline Key incentives & IP_ind2 & 0.3761 & 1 & 0 & 0.4845 & 2188 \\
\hline Government subsidy policy & Sub & 8.9514 & 12.5122 & 0 & 1.2452 & 2179 \\
\hline Special subsidies for science and technology & Techsub & 7.4822 & 12.0637 & -2.1107 & 1.7110 & 1941 \\
\hline Non-technical special subsidy & Ftechsub & 8.3309 & 12.5122 & -0.3381 & 1.5349 & 2147 \\
\hline Financial support & FS & 1.9197 & 26.3117 & 0 & 2.3106 & 1965 \\
\hline Environment system & IPO & 0.1056 & 1 & 0 & 0.3073 & 2188 \\
\hline Business scale & Size & 20.8941 & 24.2117 & 18.6794 & 0.6970 & 2188 \\
\hline Corporate cash flow & Cash & 0.3480 & 0.9603 & 0.0044 & 0.2117 & 2188 \\
\hline Asset-liability ratio & LEV & 0.2427 & 0.8864 & 0.0110 & 0.1581 & 2188 \\
\hline Current ratio & $\mathrm{CR}$ & 6.3588 & 144 & 0.38126 & 8.6600 & 2188 \\
\hline Return on total assets & $\mathrm{ROA}$ & 0.7140 & 0.5589 & -0.4620 & 0.0603 & 2188 \\
\hline Business age & Age & 12.1682 & 29 & 2 & 4.6589 & 2188 \\
\hline Adjunct & Dual & 0.4549 & 1 & 0 & 0.4980 & 2185 \\
\hline $\mathrm{R} \& \mathrm{D}$ intensity & $\mathrm{RDE}$ & 0.0690 & 0.9839 & 0 & 0.0721 & 2188 \\
\hline Regional dummy variable & Region & 0.3807 & 1 & 0 & 0.4857 & 2188 \\
\hline
\end{tabular}


this feature, has an impact on the policy effect. The group study was conducted on the two methods of industrial policy simultaneously for $\mathrm{H} 6$ and $\mathrm{H} 7$.

\section{Results}

To explore the impact of selective industrial policies on corporate innovation output, this study conducted a regression test of model 1. From the regression results in Table 3, we observe that the impact of selective industrial policies on the innovation output of entrepreneurial enterprises is not significant, whether the general level of encouragement or the key level of encouragement, so H1 is not supported.

Possible reasons for this result are as follows: first, the lag and timeliness of selective industrial policies (Lin, 2013); the "Five-Year Plan" is a national programmatic document, and specific supporting measures cannot be formulated and implemented in a timely manner, requiring a certain period of time for inspection and implementation. Thus, the current "Five-Year Plan" document's incentive effect on enterprise innovation cannot be reflected in a timely manner. Second, the innovation promotion effect of key encouragement policies is not significant. One possible reason is that, compared with the generally encouraged industries, the key encouragement industries are largely emerging industries at the stage of cultivation and development, and the demand market and technology level are not mature and perfect. This also indicates that enterprise innovation is in urgent need of government support and guidance.

Next, information agencies such as China's ratings agencies are still not perfect. Compared with developed countries, there is still a gap between them. This makes the information asymmetry between the government and enterprises more serious. It is difficult for the government to obtain complete information on the growth and technical level of the enterprise, as well as the government. The limitations of professionals in professional knowledge and practice make it difficult to foresee the technological prospects of enterprises and the right antidote [6], which makes industrial policies unable to meet the innovation needs of the most sensitive SMEs in the market, affecting the industry to some extent. This is the support effect of the policy.

Third, the ubiquitous relationship between government and enterprise distorts the government's allocation of resources such as fiscal subsidies and tax incentives, thus weakening the incentive effect of industrial policies. Enterprises are motivated to establish a good relationship with the government through various methods to obtain additional protection and support, which virtually leads to turning the government's support for enterprise innovation into a vicious circle. Meanwhile, due to their limited scale, financial resources, and accumulation of social relations, SMEs are far behind large enterprises in terms of social resources and also lack equal competition opportunities. Therefore, the support effect of industrial policies on enterprise innovation in the GEM is not significant.

Fourth, such nondiscriminatory, universal support often brings far more innovation benefits to large enterprises than to small ones. The GEM enterprises are mostly in the early
TABLE 3: The impact of general incentives (key encouragement) on the innovation output of entrepreneurial enterprises.

\begin{tabular}{|c|c|c|}
\hline & \multicolumn{2}{|c|}{ Model1 } \\
\hline IP_ind1 & $\begin{array}{c}0.0252 \\
(0.14)\end{array}$ & \\
\hline IP_ind 2 & & $\begin{array}{l}0.133 \\
(1.04)\end{array}$ \\
\hline IPO & $\begin{array}{l}0.169 \\
(1.29)\end{array}$ & $\begin{array}{l}0.164 \\
(1.26)\end{array}$ \\
\hline Size & $\begin{array}{c}0.355^{* * * *} \\
(13.08)\end{array}$ & $\begin{array}{c}0.355^{* * *} \\
(13.10)\end{array}$ \\
\hline Dual & $\begin{array}{c}-0.0253 \\
(-0.95)\end{array}$ & $\begin{array}{l}-0.0257 \\
(-0.97)\end{array}$ \\
\hline Cash & $\begin{array}{l}0.0717 \\
(0.89)\end{array}$ & $\begin{array}{c}0.0722 \\
(0.90)\end{array}$ \\
\hline LEV & $\begin{array}{c}-0.0833 \\
(-0.89)\end{array}$ & $\begin{array}{c}-0.0842 \\
(-0.90)\end{array}$ \\
\hline CR & $\begin{array}{c}-0.0167^{* * *} \\
(-8.90)\end{array}$ & $\begin{array}{c}-0.0167^{* * *} \\
(-8.91)\end{array}$ \\
\hline ROA & $\begin{array}{c}1.316^{* * *} \\
(7.08)\end{array}$ & $\begin{array}{c}1.318^{* * *} \\
(7.10)\end{array}$ \\
\hline $\mathrm{RDE}$ & $\begin{array}{c}2.413^{* * * *} \\
(11.32)\end{array}$ & $\begin{array}{c}2.419^{* * *} \\
(11.35)\end{array}$ \\
\hline Age & $\begin{array}{c}-0.0117 \\
(-0.91)\end{array}$ & $\begin{array}{l}-0.0121 \\
(-0.95)\end{array}$ \\
\hline Region & $\begin{array}{l}-0.0963 \\
(-0.92)\end{array}$ & $\begin{array}{c}-0.0874 \\
(-0.84)\end{array}$ \\
\hline $\begin{array}{l}\text { Industry } \\
\text { Year }\end{array}$ & $\begin{array}{l}\text { Yes } \\
\text { Yes }\end{array}$ & $\begin{array}{l}\text { Yes } \\
\text { Yes }\end{array}$ \\
\hline Constant & $\begin{array}{c}-6.017^{* * *} \\
(-9.31)\end{array}$ & $\begin{array}{c}-5.956^{* * *} \\
(-9.27)\end{array}$ \\
\hline $\begin{array}{l}\text { Log likelihood } \\
N\end{array}$ & $\begin{array}{c}-10415.8 \\
2181\end{array}$ & $\begin{array}{c}-10415.3 \\
2181\end{array}$ \\
\hline
\end{tabular}

${ }^{*},{ }^{* *}$, and ${ }^{* * *}$, respectively, indicated that they passed the test at the significance level of $10 \%, 5 \%$, and $1 \%$.

stage of development or growth stage, with a short time of establishment, immature business model, and relatively small scale. Even if encouraged by national policies, they tend to pursue overall benefits and put more energy and resources into enterprise growth rather than technology R\&D and innovation. On the contrary, mature and stable business activities pay more attention to enterprise innovation. Yu Minggui [23], taking the main board listed companies as research samples, concluded that industrial policy can significantly increase the number of invention patents of enterprises in the encouraged industries, and industrial policy in the key industries has a greater impact on enterprise innovation than general encouragement.

We posit that the support effect of selective industrial policy on entrepreneurial innovation is not significant in the short term but will gradually deepen and be reflected over time.

This section examines the role of specific industrial policy instruments on the innovation output of entrepreneurial enterprises and verifies $\mathrm{H} 2, \mathrm{H} 3$, and $\mathrm{H} 4$. The Poisson regression results are presented in Table 4.

In model 2, Sub's coefficient estimate is 0.0002 , which is not significant. This indicates that government subsidies have no substantial impact on entrepreneurial innovation output, and $\mathrm{H} 2$ is not supported. Possible reasons are as follows. 
TABLE 4: Impact of government subsidy policy and financial support policy on entrepreneurial innovation.

\begin{tabular}{|c|c|c|c|c|}
\hline & \multicolumn{2}{|c|}{ Model2 } & \multicolumn{2}{|c|}{ Model3 } \\
\hline Sub & $\begin{array}{l}0.0002 \\
(0.02)\end{array}$ & & & \\
\hline Techsub & & $\begin{array}{c}0.0241^{* * *} \\
(3.63)\end{array}$ & & \\
\hline Ftechsub & & & $\begin{array}{c}-0.0031 \\
(-0.47)\end{array}$ & \\
\hline FS & & & & $\begin{array}{c}-0.0177^{* * *} \\
(-3.62)\end{array}$ \\
\hline IPO & $\begin{array}{c}0.168 \\
(1.3)\end{array}$ & $\begin{array}{l}0.163 \\
(1.28)\end{array}$ & $\begin{array}{l}0.162 \\
(1.25)\end{array}$ & $\begin{array}{l}0.183 \\
(1.37)\end{array}$ \\
\hline Size & $\begin{array}{c}0.352^{* * *} \\
(12.94)\end{array}$ & $\begin{array}{c}0.233^{* * *} \\
(8.05)\end{array}$ & $\begin{array}{c}0.350^{* * *} \\
(12.87)\end{array}$ & $\begin{array}{c}0.350^{* * *} \\
(12.18)\end{array}$ \\
\hline Dual & $\begin{array}{c}-0.0269 \\
(-1.01)\end{array}$ & $\begin{array}{c}0.0570^{* *} \\
(1.95)\end{array}$ & $\begin{array}{c}-0.0228 \\
(-0.85)\end{array}$ & $\begin{array}{c}-0.0467^{*} \\
(-1.68)\end{array}$ \\
\hline Cash & $\begin{array}{c}0.0755 \\
(0.94)\end{array}$ & $\begin{array}{c}-0.00709 \\
(-0.08)\end{array}$ & $\begin{array}{c}0.0907 \\
(1.13)\end{array}$ & $\begin{array}{c}0.256^{* * *} \\
(3.02)\end{array}$ \\
\hline LEV & $\begin{array}{c}-0.0819 \\
(-0.87)\end{array}$ & $\begin{array}{c}-0.378^{* * *} \\
(-3.81)\end{array}$ & $\begin{array}{c}-0.0614 \\
(-0.65)\end{array}$ & $\begin{array}{c}-0.0203 \\
(-0.21)\end{array}$ \\
\hline CR & $\begin{array}{c}-0.0168^{* * *} \\
(-8.94)\end{array}$ & $\begin{array}{c}-0.0160^{* * *} \\
(-8.37)\end{array}$ & $\begin{array}{c}-0.0164^{* * *} \\
(-8.78)\end{array}$ & $\begin{array}{c}-0.0167^{* * *} \\
(-7.42)\end{array}$ \\
\hline ROA & $\begin{array}{c}1.308^{* * *} \\
(6.95)\end{array}$ & $\begin{array}{c}0.841^{* * *} \\
(4.07)\end{array}$ & $\begin{array}{c}1.324^{* * *} \\
(7.08)\end{array}$ & $\begin{array}{c}1.669^{* * *} \\
(8.32)\end{array}$ \\
\hline $\mathrm{RDE}$ & $\begin{array}{c}2.399^{* * *} \\
(11.13)\end{array}$ & $\begin{array}{c}1.758^{* * *} \\
(7.98)\end{array}$ & $\begin{array}{c}2.252^{* * *} \\
(10.31)\end{array}$ & $\begin{array}{c}3.211^{* * *} \\
(13.10)\end{array}$ \\
\hline Age & $\begin{array}{c}-0.00994 \\
(-0.79)\end{array}$ & $\begin{array}{c}-0.0138 \\
(-1.13)\end{array}$ & $\begin{array}{c}-0.0103 \\
(-0.81)\end{array}$ & $\begin{array}{c}-0.0147 \\
(-1.14)\end{array}$ \\
\hline Region & $\begin{array}{l}-0.103 \\
(-0.98)\end{array}$ & $\begin{array}{c}-0.0523 \\
(-0.51)\end{array}$ & $\begin{array}{c}-0.0937 \\
(-0.90)\end{array}$ & $\begin{array}{l}-0.129 \\
(-1.22)\end{array}$ \\
\hline Industry & Yes & Yes & Yes & Yes \\
\hline Year & Yes & Yes & Yes & Yes \\
\hline Constant & $\begin{array}{c}-5.922^{* * *} \\
(-9.22)\end{array}$ & $\begin{array}{c}-3.028^{* * *} \\
(-4.47)\end{array}$ & $\begin{array}{c}-5.882^{* * *} \\
(-9.15)\end{array}$ & $\begin{array}{c}-5.895^{* * *} \\
(-8.76)\end{array}$ \\
\hline Log likelihood & -10384.3 & -9391.85 & -10290.1 & -9383.2 \\
\hline$N$ & 2176 & 1938 & 2144 & 1962 \\
\hline
\end{tabular}

${ }^{*},{ }^{* *}$, and ${ }^{* * *}$, respectively, indicated that they passed the test at the significance level of $10 \%, 5 \%$, and $1 \%$.

First, there are many types of government subsidies. Most of them are not specifically targeted at scientific and technological innovation or R\&D support, such as the listing of incentives for startup companies. The state's support for certain utilities or socially necessary products only encourages and supports specific industries. These subsidies do not directly affect the R\&D of enterprises and technological innovation, and enterprises often have the right to control them. The government's application of this aspect of subsidies and the direction is not supervised and intervened, and startups are likely to choose uses other than $R \& D$ innovation.

Second, the government's financial subsidies based on political connections can distort the effective allocation of scarce resources in society [23]. Government subsidies to startup enterprises will objectively motivate these enterprises to establish a good social relationship with the local government so as to obtain additional policy support, that is, "rent seeking." The prevalence of government-enterprise relations makes it inevitable for the government to choose entrepreneurial enterprises with good relations when selecting funding targets, rather than entrepreneurs with strong technological innovation needs or strong innovation strength.

Third, most startups are in the early stages of development or in the growth stage. Even when government subsidies are used to boost firms' ability to innovate, they are often subject to technological constraints or R\&D shortfalls that do not necessarily boost patent output.

The Tech subcoefficient in model 2 is positive $(\beta 1=0.0241, p<0.01)$, which indicates the positive promotion effect of special subsidies for science and technology on the innovation output of entrepreneurs. The coefficient of Ftechsub is not significant, indicating that nontechnical special subsidies have no obvious effect on corporate patent applications. This result supports $\mathrm{H} 3$. We believe that special subsidies for science and technology can better eliminate the negative externalities of enterprise innovation to a certain extent, ease the gap between private income and social benefits of innovation activities, and provide support in resources, funds, or systems to enhance enthusiasm for innovation.

Finally, the impact of the coefficient of FS on innovation output in model 3 is negative $(\beta 1=-0.0177, p<0.01)$. Since FS is measured by the ratio of interest expenses to current liabilities, a negative coefficient indicates positive FS. Therefore, the regression results indicate that the company's patent applications have increased in response to FS, providing evidence for $\mathrm{H} 4$.

Accordingly, the FS provided by the government to enterprises can alleviate the financing constraints and capital bottlenecks faced by entrepreneurial innovation, reduce the risk of innovation investment, improve the external environment faced by enterprises, and ultimately promote the innovation output of enterprises.

Table 5 reports the regression results of models 4 and 5, indicating the regulatory role of corporate $\mathrm{R} \& \mathrm{D}$ intensity in the process of policy impacting innovation output.

The coefficient of techsub*rde $(\beta 1=0.741, p<0.01)$ in model 4 and the coefficient of $\mathrm{fs}^{*}$ rde in model 5 ( $\beta 1=0.0507$, $p<0.05)$ are both positive and significant, indicating that in enterprises with high R\&D intensity, science and technology special projects, and FS have a higher promoting effect on entrepreneurial enterprises' innovation output. Therefore, when the abovementioned individual research on the impact of industrial policy instruments on innovation output may underestimate the actual effect of the policy, the R\&D intensity of the enterprise is indeed the core element of enterprise innovation and has a leading effect on the policy effect. Next, the interaction terms of Ftechsub, Sub, and rde are negative, indicating that $\mathrm{R} \& \mathrm{D}$ intensity does not play a good role in the nontechnical special subsidy form (see Table 2). In summary, the Poisson regression results in Table 5 provide complete support for $\mathrm{H} 5$, that is, when the policy means the special subsidy for science and technology and the form of FS, the positive adjustment effect of R\&D intensity is obvious.

The adjustment of $R \& D$ intensity is obvious in the form of special subsidies for science and technology and FS. The possible reasons are as follows: first, China's GEM enterprises 
TABLE 5: Regulation of R\&D intensity.

\begin{tabular}{|c|c|c|c|c|}
\hline & Model 4 & & Model 5 & \\
\hline Sub & $\begin{array}{c}0.0903^{* * *} \\
(7.22)\end{array}$ & & & \\
\hline Techsub & & $\begin{array}{c}0.0752^{* * *} \\
(8.71)\end{array}$ & & \\
\hline Ftechsub & & & $\begin{array}{c}0.0407^{* * *} \\
(4.10)\end{array}$ & \\
\hline FS & & & & $\begin{array}{c}-0.0260^{* * *} \\
(-3.73)\end{array}$ \\
\hline sub*rde & $\begin{array}{c}-1.332^{* * *} \\
(-12.42)\end{array}$ & & & \\
\hline Techsub*rde & & $\begin{array}{c}0.741^{* * *} \\
(9.49)\end{array}$ & & \\
\hline Ftechsub* rde & & & $\begin{array}{c}-0.618^{* * *} \\
(-5.97)\end{array}$ & \\
\hline $\mathrm{fs}^{*} \mathrm{rde}$ & & & & $\begin{array}{c}0.0507^{* *} \\
(2.15)\end{array}$ \\
\hline RDE & $\begin{array}{c}15.78^{* * *} \\
(14.44)\end{array}$ & $\begin{array}{c}1.786^{* * *} \\
(8.20)\end{array}$ & $\begin{array}{c}7.868^{* * *} \\
(8.18)\end{array}$ & $\begin{array}{c}3.107^{* * *} \\
(12.64)\end{array}$ \\
\hline IPO & $\begin{array}{l}0.149 \\
(1.14)\end{array}$ & $\begin{array}{l}0.133 \\
(1.04)\end{array}$ & $\begin{array}{l}0.169 \\
(1.29)\end{array}$ & $\begin{array}{l}0.185 \\
(1.39)\end{array}$ \\
\hline Size & $\begin{array}{c}0.343^{* * *} \\
(12.52)\end{array}$ & $\begin{array}{c}0.223^{* * *} \\
(7.65)\end{array}$ & $\begin{array}{c}0.351^{* * *} \\
(12.86)\end{array}$ & $\begin{array}{c}0.349^{* * *} \\
(12.13)\end{array}$ \\
\hline Dual & $\begin{array}{c}-0.0250 \\
(-0.94)\end{array}$ & $\begin{array}{c}0.0675^{* *} \\
(2.31)\end{array}$ & $\begin{array}{c}-0.0247 \\
(-0.92)\end{array}$ & $\begin{array}{c}-0.0480^{*} \\
(-1.73)\end{array}$ \\
\hline Cash & $\begin{array}{l}0.0511 \\
(0.64)\end{array}$ & $\begin{array}{c}-0.0208 \\
(-0.24)\end{array}$ & $\begin{array}{l}0.0661 \\
(0.82)\end{array}$ & $\begin{array}{c}0.269^{* * * *} \\
(3.15)\end{array}$ \\
\hline LEV & $\begin{array}{l}-0.143 \\
(-1.50)\end{array}$ & $\begin{array}{c}-0.420^{* * *} \\
(-4.21)\end{array}$ & $\begin{array}{c}-0.0781 \\
(-0.83)\end{array}$ & $\begin{array}{c}-0.0265 \\
(-0.27)\end{array}$ \\
\hline CR & $\begin{array}{c}-0.0177^{* * *} \\
(-9.38)\end{array}$ & $\begin{array}{c}-0.0160^{* * *} \\
(-8.43)\end{array}$ & $\begin{array}{c}-0.0168^{* * *} \\
(-8.93)\end{array}$ & $\begin{array}{c}-0.0165^{* * *} \\
(-7.35)\end{array}$ \\
\hline ROA & $\begin{array}{c}1.403^{* * *} \\
(7.47)\end{array}$ & $\begin{array}{c}1.016^{* * * *} \\
(4.90)\end{array}$ & $\begin{array}{c}1.287^{* * * *} \\
(6.87)\end{array}$ & $\begin{array}{c}1.632^{* * *} \\
(8.09)\end{array}$ \\
\hline Age & $\begin{array}{c}-0.0125 \\
(-0.97)\end{array}$ & $\begin{array}{c}-0.0146 \\
(-1.19)\end{array}$ & $\begin{array}{c}-0.0117 \\
(-0.91)\end{array}$ & $\begin{array}{c}-0.0146 \\
(-1.14)\end{array}$ \\
\hline Region & $\begin{array}{l}-0.120 \\
(-1.15)\end{array}$ & $\begin{array}{c}-0.0616 \\
(-0.59)\end{array}$ & $\begin{array}{c}-0.0998 \\
(-0.96)\end{array}$ & $\begin{array}{l}-0.125 \\
(-1.18)\end{array}$ \\
\hline Industry & Yes & Yes & Yes & Yes \\
\hline Year & Yes & Yes & Yes & Yes \\
\hline Constant & $\begin{array}{c}-6.531^{* * *} \\
(-10.03)\end{array}$ & $\begin{array}{c}-2.726^{* * *} \\
(-3.99)\end{array}$ & $\begin{array}{c}-6.237^{* * *} \\
(-9.63)\end{array}$ & $\begin{array}{c}* * * \\
(-8.68)\end{array}$ \\
\hline $\begin{array}{l}\text { Log } \\
\text { likelihood }\end{array}$ & -10305.14 & -9346.6566 & -10272.532 & -9377.922 \\
\hline$N$ & 2172 & 1938 & 2140 & 1962 \\
\hline
\end{tabular}

${ }^{*},{ }^{* *}$, and ${ }^{* * *}$, respectively, indicated that they passed the test at the significance level of $10 \%, 5 \%$, and $1 \%$.

are primarily in the early stages of development or growth, and the proportion of manufacturing and technology industries is large. Therefore, GEM enterprises need a large number of R\&D funds for their business development. Effectively increasing the intensity of $\mathrm{R} \& \mathrm{D}$ can promote the development of innovative activities. Second, most GEM enterprises are private enterprises. Compared with state-owned enterprises, their organization structures are flexible and more innovative, which makes them value the government's special support for science and technology, and can improve the allocation efficiency of funds. R\&D investment can play a better role in promoting $\mathrm{R} \& \mathrm{D}$. Third, $\mathrm{R} \& \mathrm{D}$ intensity in research, using the ratio of $\mathrm{R} \& \mathrm{D}$ investment to operating income, represents the unit revenue spent on $R \& D$ projects. A high $R \& D$ intensity indicates that the internal decision-making layer of the company attaches great importance to the R\&D of products or technologies, and enterprises that attach importance to innovation usually have more abundant innovation output. Fourth, increasing the intensity of R\&D investment is conducive to improving the technical level of enterprises and promoting continuous innovation of enterprises. After the implementation of $\mathrm{R} \& \mathrm{D}$ projects, companies often require continuous investment in R\&D. Special subsidies for science and technology and FS can help companies avoid capital chain breaks and achieve continuous innovation. R\&D intensity plays an indispensable intermediate link in this process and plays a key role in innovation output.

Table 6 reports the impact of government subsidies and FS on innovation output in entrepreneurial conglomerates in different regions. The coefficient of Techsub in model 2 is significantly positive in both the developed and underdeveloped groups, and the Sub and Ftechsub coefficients are still not significant. The coefficients of FS in model 3 are significantly negative in groups in different regions. This implies that special subsidies for science and technology and FS can significantly promote the innovation output of enterprises. The promotion of industrial policies in nondeveloped regions is slightly stronger than that in developed regions. H6 did not get clear evidence from the empirical research. The possible reasons are as follows: enterprises may face considerable constraints in nondeveloped regions; consequently, the effect of technology subsidies and FS on innovation is prominent. In addition, relevant conclusions can be derived: China's industrial policies cover a wide range, and local governments can respond to China's industrial policies at a basic level; the industrial structure between different regions is similar, and the types of industries tend to be "full"; the enthusiasm for innovation among GEM companies is generally high, and there is almost no geographical difference.

The next step is to examine the impact of different corporate leadership structures in groups (see Table 7). The results of model 2 show that the impact coefficients of Sub and Ftechsub on patent applications are not significant. Tech sub's influence on patent applications is 0.027 , which is significant at the $1 \%$ level. In the General Manager and concurrently enterprise, the influence coefficient is 0.017 , which is significant at the $10 \%$ level, that is, it is significantly positive in both the part-time and the suboffice, but the former has a higher level of significance. The results of model 3 found that the influence coefficient of FS on innovation was not significant in the concurrent enterprises; in the "two-job separation" enterprises, the coefficient of FS was significantly negative $(\beta 1=-0.022, p<0.01)$. This shows that, among the enterprises where the Chairman and General Manager are divided, the promotion of science and technology special subsidies and FS to the innovation output of entrepreneurial enterprises is more effective than the twopart enterprises, and $\mathrm{H} 7$ is established.

Possible reasons for this result may be: first, the "separation of the two positions" can avoid the excessive concentration of power, ensure effective supervision and 
TABLE 6: Grouping study of regional characteristics.

\begin{tabular}{|c|c|c|c|c|c|c|c|c|}
\hline & \multicolumn{4}{|c|}{ Model 2} & \multicolumn{4}{|c|}{ Model 3} \\
\hline & Developed & Undeveloped & Developed & Undeveloped & Developed & Undeveloped & Developed & Undeveloped \\
\hline Sub & $\begin{array}{c}-0.0104 \\
(-0.63)\end{array}$ & $\begin{array}{c}0.0180 \\
(1.38)\end{array}$ & & & & & & \\
\hline Techsub & & & $\begin{array}{c}0.0324^{* * *} \\
(3.09)\end{array}$ & $\begin{array}{c}0.0334^{* * *} \\
(3.82)\end{array}$ & & & & \\
\hline Ftechsub & & & & & $\begin{array}{l}0.0045 \\
(0.38)\end{array}$ & $\begin{array}{c}-0.0032 \\
(-0.40)\end{array}$ & & \\
\hline FS & & & & & & & $\begin{array}{l}0.0003 \\
(0.03)\end{array}$ & $\begin{array}{c}-0.022^{* * *} \\
(-3.44)\end{array}$ \\
\hline IPO & $\begin{array}{l}0.203 \\
(0.75)\end{array}$ & $\begin{array}{l}0.146 \\
(1.00)\end{array}$ & $\begin{array}{c}0.131 \\
(0.51)\end{array}$ & $\begin{array}{l}0.147 \\
(1.01)\end{array}$ & $\begin{array}{c}0.172 \\
(0.63)\end{array}$ & $\begin{array}{c}0.140 \\
(0.95)\end{array}$ & $\begin{array}{c}0.201 \\
(0.68)\end{array}$ & $\begin{array}{c}0.146 \\
(0.98)\end{array}$ \\
\hline Size & $\begin{array}{c}0.576^{* * *} \\
(12.62)\end{array}$ & $\begin{array}{c}0.221^{* * *} \\
(6.34)\end{array}$ & $\begin{array}{c}0.489^{* * *} \\
(10.25)\end{array}$ & $\begin{array}{c}0.0571 \\
(1.52)\end{array}$ & $\begin{array}{c}0.572^{* * *} \\
(12.50)\end{array}$ & $\begin{array}{c}0.220^{* * *} \\
(6.31)\end{array}$ & $\begin{array}{c}0.513^{* * *} \\
(10.48)\end{array}$ & $\begin{array}{c}0.238^{* * *} \\
(6.45)\end{array}$ \\
\hline Dual & $\begin{array}{c}0.0674 \\
(1.58)\end{array}$ & $\begin{array}{c}-0.107^{* * *} \\
(-3.08)\end{array}$ & $\begin{array}{c}0.0742^{*} \\
(1.68)\end{array}$ & $\begin{array}{c}0.0613^{*} \\
(1.55)\end{array}$ & $\begin{array}{c}0.0868^{* *} \\
(2.00)\end{array}$ & $\begin{array}{c}-0.109^{* * *} \\
(-3.13)\end{array}$ & $\begin{array}{c}0.933^{* * *} \\
(6.44)\end{array}$ & $\begin{array}{c}-0.307^{* * *} \\
(-2.84)\end{array}$ \\
\hline Cash & $\begin{array}{c}0.499^{* * *} \\
(3.75)\end{array}$ & $\begin{array}{c}-0.329^{* * *} \\
(-3.20)\end{array}$ & $\begin{array}{c}0.739^{* * *} \\
(5.40)\end{array}$ & $\begin{array}{c}-0.755^{* * *} \\
(-6.61)\end{array}$ & $\begin{array}{c}0.562^{* * *} \\
(4.20)\end{array}$ & $\begin{array}{c}-0.325^{* * *} \\
(-3.15)\end{array}$ & $\begin{array}{l}-0.175 \\
(-0.98)\end{array}$ & $\begin{array}{l}-0.192 \\
(-1.54)\end{array}$ \\
\hline LEV & $\begin{array}{l}-0.247 \\
(-1.47)\end{array}$ & $\begin{array}{l}-0.186 \\
(-1.57)\end{array}$ & $\begin{array}{c}-0.649^{* * *} \\
(-3.59)\end{array}$ & $\begin{array}{c}-0.524^{* * *} \\
(-4.22)\end{array}$ & $\begin{array}{l}-0.182 \\
(-1.08)\end{array}$ & $\begin{array}{l}-0.178 \\
(-1.50)\end{array}$ & $\begin{array}{c}-0.015^{* * *} \\
(-4.36)\end{array}$ & $\begin{array}{c}-0.024^{* * *} \\
(-7.16)\end{array}$ \\
\hline CR & $\begin{array}{c}-0.019^{* * * *} \\
(-6.83)\end{array}$ & $\begin{array}{c}-0.02^{* * *} \\
(-7.11)\end{array}$ & $\begin{array}{c}-0.023^{* * *} \\
(-7.91)\end{array}$ & $\begin{array}{c}-0.015^{* * *} \\
(-5.55)\end{array}$ & $\begin{array}{c}-0.018^{* * * *} \\
(-6.68)\end{array}$ & $\begin{array}{c}-0.019^{* * * *} \\
(-7.03)\end{array}$ & $\begin{array}{c}0.101^{* * *} \\
(2.27)\end{array}$ & $\begin{array}{c}-0.155^{* * *} \\
(-4.28)\end{array}$ \\
\hline ROA & $\begin{array}{c}1.841^{* * *} \\
(5.68)\end{array}$ & $\begin{array}{c}1.098^{* * *} \\
(4.57)\end{array}$ & $\begin{array}{c}1.626^{* * *} \\
(5.01)\end{array}$ & $\begin{array}{c}0.494^{*} \\
(1.77)\end{array}$ & $\begin{array}{c}1.944^{* * *} \\
(6.00)\end{array}$ & $\begin{array}{c}1.116^{* * *} \\
(4.68)\end{array}$ & $\begin{array}{c}1.972^{* * *} \\
(5.81)\end{array}$ & $\begin{array}{c}1.371^{* * *} \\
(5.35)\end{array}$ \\
\hline $\mathrm{RDE}$ & $\begin{array}{c}3.263^{* * *} \\
(11.14)\end{array}$ & $\begin{array}{c}1.342^{* * *} \\
(3.72)\end{array}$ & $\begin{array}{c}2.440^{* * * *} \\
(8.14)\end{array}$ & $\begin{array}{c}0.767^{* *} \\
(2.06)\end{array}$ & $\begin{array}{c}2.987^{* * *} \\
(9.96)\end{array}$ & $\begin{array}{c}1.342^{* * *} \\
(3.73)\end{array}$ & $\begin{array}{c}4.808^{* * *} \\
(13.75)\end{array}$ & $\begin{array}{c}1.141^{* * * *} \\
(2.97)\end{array}$ \\
\hline Age & $\begin{array}{c}-0.0284 \\
(-1.14)\end{array}$ & $\begin{array}{c}0.00438 \\
(0.29)\end{array}$ & $\begin{array}{c}-0.0417^{*} \\
(-1.79)\end{array}$ & $\begin{array}{c}0.00734 \\
(0.50)\end{array}$ & $\begin{array}{c}-0.0294 \\
(-1.19)\end{array}$ & $\begin{array}{c}0.00435 \\
(0.29)\end{array}$ & $\begin{array}{c}-0.0341 \\
(-1.32)\end{array}$ & $\begin{array}{c}0.00150 \\
(0.10)\end{array}$ \\
\hline Industry & Yes & Yes & Yes & Yes & Yes & Yes & Yes & Yes \\
\hline Year & Yes & Yes & Yes & Yes & Yes & Yes & Yes & Yes \\
\hline Constant & $\begin{array}{c}-10.59^{* * *} \\
(-9.58)\end{array}$ & $\begin{array}{c}-3.314^{* * *} \\
(-4.10)\end{array}$ & $\begin{array}{c}-8.537^{* * *} \\
(-7.50)\end{array}$ & $\begin{array}{l}0.434 \\
(0.50)\end{array}$ & $\begin{array}{c}-10.63^{* * *} \\
(-9.64)\end{array}$ & $\begin{array}{c}-3.114^{* * *} \\
(-3.84)\end{array}$ & $\begin{array}{c}-9.418^{* * *} \\
(-8.08)\end{array}$ & $\begin{array}{c}-3.430^{* * *} \\
(-4.03)\end{array}$ \\
\hline $\begin{array}{l}\text { Log likelihood } \\
N\end{array}$ & $\begin{array}{c}-3871.185 \\
825\end{array}$ & $\begin{array}{c}-6409.610 \\
1347\end{array}$ & $\begin{array}{c}-3628.640 \\
728\end{array}$ & $\begin{array}{c}-5620.57 \\
1210\end{array}$ & $\begin{array}{c}-3799.756 \\
803\end{array}$ & $\begin{array}{c}-6384.763 \\
1337\end{array}$ & $\begin{array}{c}-3349.545 \\
721\end{array}$ & $\begin{array}{c}-5877.711 \\
1241\end{array}$ \\
\hline
\end{tabular}

${ }^{*},{ }^{* *}$, and ${ }^{* * *}$, respectively, indicated that they passed the test at the significance level of $10 \%, 5 \%$, and $1 \%$.

TABLE 7: Grouping study of corporate governance characteristics.

\begin{tabular}{|c|c|c|c|c|c|c|c|c|}
\hline & \multicolumn{4}{|c|}{ Model 2} & \multicolumn{4}{|c|}{ Model 3} \\
\hline & Adjunct & Nonparticipating & Adjunct & Nonparticipating & Adjunct & Nonparticipating & Adjunct & Nonparticipating \\
\hline Sub & $\begin{array}{l}0.0307 \\
(1.96)\end{array}$ & $\begin{array}{l}0.0136 \\
(0.94)\end{array}$ & & & & & & \\
\hline Techsub & & & $\begin{array}{c}0.017^{*} \\
(1.72)\end{array}$ & $\begin{array}{c}0.027^{* * *} \\
(2.78)\end{array}$ & 0.0007 & 0.0047 & & \\
\hline Ftechsub & & & & & $(0.06)$ & $(0.53)$ & & \\
\hline FS & & & & & & & $\begin{array}{c}-0.0016 \\
(-0.19)\end{array}$ & $\begin{array}{c}-0.022^{* * *} \\
(-3.35)\end{array}$ \\
\hline IPO & $\begin{array}{l}0.0987 \\
(0.55)\end{array}$ & $\begin{array}{l}0.133 \\
(0.75)\end{array}$ & $\begin{array}{l}0.175 \\
(0.96)\end{array}$ & $\begin{array}{l}0.0928 \\
(0.55)\end{array}$ & $\begin{array}{c}0.0762 \\
(0.42)\end{array}$ & $\begin{array}{l}0.130 \\
(0.73)\end{array}$ & $\begin{array}{l}0.178 \\
(0.94)\end{array}$ & $\begin{array}{c}0.0324 \\
(0.18)\end{array}$ \\
\hline Size & $\begin{array}{c}0.436^{* * *} \\
(10.75)\end{array}$ & $\begin{array}{c}0.235^{* * *} \\
(5.92)\end{array}$ & $\begin{array}{c}0.306^{* * *} \\
(7.00)\end{array}$ & $\begin{array}{c}0.108^{* *} \\
(2.52)\end{array}$ & $\begin{array}{c}0.440^{* * *} \\
(10.86)\end{array}$ & $\begin{array}{c}0.228^{* * *} \\
(5.73)\end{array}$ & $\begin{array}{c}0.525^{* * *} \\
(12.25)\end{array}$ & $\begin{array}{c}0.164^{* * *} \\
(3.86)\end{array}$ \\
\hline Cash & $\begin{array}{c}-0.215^{*} \\
(-1.79)\end{array}$ & $\begin{array}{c}0.0659 \\
(0.55)\end{array}$ & $\begin{array}{c}-0.58^{* * *} \\
(-4.50)\end{array}$ & $\begin{array}{c}0.34^{* * *} \\
(2.64)\end{array}$ & $\begin{array}{l}-0.226^{*} \\
(-1.88)\end{array}$ & $\begin{array}{r}0.0847 \\
(0.71)\end{array}$ & $\begin{array}{l}0.122 \\
(0.94)\end{array}$ & $\begin{array}{c}0.0694 \\
(0.55)\end{array}$ \\
\hline LEV & $\begin{array}{l}-0.192 \\
(-1.40)\end{array}$ & $\begin{array}{l}-0.0808 \\
(-0.55)\end{array}$ & $\begin{array}{c}-0.88^{* * *} \\
(-5.95)\end{array}$ & $\begin{array}{l}-0.0048 \\
(-0.03)\end{array}$ & $\begin{array}{l}-0.150 \\
(-1.09)\end{array}$ & $\begin{array}{c}-0.0865 \\
(-0.58)\end{array}$ & $\begin{array}{l}-0.151 \\
(-1.04)\end{array}$ & $\begin{array}{c}-0.000923 \\
(-0.01)\end{array}$ \\
\hline $\mathrm{CR}$ & $\begin{array}{c}-0.01^{* * *} \\
(-3.70)\end{array}$ & $\begin{array}{c}-0.02^{* * *} \\
(-6.16)\end{array}$ & $\begin{array}{l}-0.01^{* *} \\
(-2.27)\end{array}$ & $\begin{array}{c}-0.02^{* * *} \\
(-7.24)\end{array}$ & $\begin{array}{c}-0.01^{* * *} \\
(-3.65)\end{array}$ & $\begin{array}{c}-0.02^{* * *} \\
(-6.17)\end{array}$ & $\begin{array}{c}-0.01^{* * *} \\
(-3.35)\end{array}$ & $\begin{array}{c}-0.01^{* * * *} \\
(-4.01)\end{array}$ \\
\hline ROA & $\begin{array}{c}2.27^{* * *} \\
(7.38)\end{array}$ & $\begin{array}{l}0.53^{*} \\
(1.95)\end{array}$ & $\begin{array}{c}1.35^{* * *} \\
(4.01)\end{array}$ & $\begin{array}{l}0.79^{* * *} \\
(2.66)\end{array}$ & $\begin{array}{c}2.38^{* * *} \\
(7.79)\end{array}$ & $\begin{array}{l}0.52^{*} \\
(1.90)\end{array}$ & $\begin{array}{c}3.11^{* * *} \\
(9.49)\end{array}$ & $\begin{array}{c}1.02^{* * *} \\
(3.52)\end{array}$ \\
\hline
\end{tabular}


TABLE 7: Continued.

\begin{tabular}{|c|c|c|c|c|c|c|c|c|}
\hline & \multicolumn{4}{|c|}{ Model 2} & \multicolumn{4}{|c|}{ Model 3} \\
\hline & Adjunct & Nonparticipating & Adjunct & Nonparticipating & Adjunct & Nonparticipating & Adjunct & Nonparticipating \\
\hline $\mathrm{RDE}$ & $\begin{array}{c}2.98^{* * *} \\
(9.31)\end{array}$ & $\begin{array}{r}1.63^{* * *} \\
(4.82)\end{array}$ & $\begin{array}{c}2.33^{* * *} \\
(7.13)\end{array}$ & $\begin{array}{c}0.92^{* * *} \\
(2.66)\end{array}$ & $\begin{array}{c}2.80^{* * *} \\
(8.52)\end{array}$ & $\begin{array}{r}1.59^{* * *} \\
(4.69)\end{array}$ & $\begin{array}{c}3.19^{* * *} \\
(9.02)\end{array}$ & $\begin{array}{c}3.38^{* * *} \\
(8.62)\end{array}$ \\
\hline Age & $\begin{array}{c}-0.0201 \\
(-1.21)\end{array}$ & $\begin{array}{c}-0.0171 \\
(-1.03)\end{array}$ & $\begin{array}{l}-0.028^{*} \\
(-1.74)\end{array}$ & $\begin{array}{l}-0.0122 \\
(-0.77)\end{array}$ & $\begin{array}{c}-0.0183 \\
(-1.10)\end{array}$ & $\begin{array}{c}-0.0173 \\
(-1.04)\end{array}$ & $\begin{array}{c}-0.0223 \\
(-1.33)\end{array}$ & $\begin{array}{c}-0.0175 \\
(-1.03)\end{array}$ \\
\hline Region & $\begin{array}{l}-0.204^{*} \\
(-1.68)\end{array}$ & $\begin{array}{l}-0.0611 \\
(-0.38)\end{array}$ & $\begin{array}{l}-0.0725 \\
(-0.59)\end{array}$ & $\begin{array}{l}0.0302 \\
(0.20)\end{array}$ & $\begin{array}{l}-0.167 \\
(-1.36)\end{array}$ & $\begin{array}{l}-0.0584 \\
(-0.37)\end{array}$ & $\begin{array}{c}-0.254^{* *} \\
(-2.07)\end{array}$ & $\begin{array}{l}-0.117 \\
(-0.72)\end{array}$ \\
\hline $\begin{array}{l}\text { Industry } \\
\text { Year }\end{array}$ & $\begin{array}{l}\text { Yes } \\
\text { Yes }\end{array}$ & $\begin{array}{l}\text { Yes } \\
\text { Yes }\end{array}$ & $\begin{array}{l}\text { Yes } \\
\text { Yes }\end{array}$ & $\begin{array}{l}\text { Yes } \\
\text { Yes }\end{array}$ & $\begin{array}{l}\text { Yes } \\
\text { Yes }\end{array}$ & $\begin{array}{l}\text { Yes } \\
\text { Yes }\end{array}$ & $\begin{array}{l}\text { Yes } \\
\text { Yes }\end{array}$ & $\begin{array}{l}\text { Yes } \\
\text { Yes }\end{array}$ \\
\hline Constant & $\begin{array}{c}-8.18^{* * *} \\
(-8.82)\end{array}$ & $\begin{array}{c}-3.11^{* * *} \\
(-3.31)\end{array}$ & $\begin{array}{c}-4.68^{* * *} \\
(-4.69)\end{array}$ & $\begin{array}{c}-0.49 \\
(-0.49)\end{array}$ & $\begin{array}{c}-7.99^{* * *} \\
(-8.62)\end{array}$ & $\begin{array}{c}-2.86^{* * *} \\
(-3.06)\end{array}$ & $\begin{array}{c}-9.88^{* * *} \\
(-10.18)\end{array}$ & $\begin{array}{c}-1.43 \\
(-1.45)\end{array}$ \\
\hline $\begin{array}{l}\text { Log } \\
\text { likelihood }\end{array}$ & -4654.952 & -5401.916 & -4129.150 & -4964.780 & -4593.495 & -5376.288 & -4118.095 & -4903.139 \\
\hline$N$ & 989 & 1183 & 870 & 1068 & 970 & 1170 & 880 & 1082 \\
\hline
\end{tabular}

${ }^{*},{ }^{* *}$, and ${ }^{* * *}$, respectively, indicated that they passed the test at the significance level of $10 \%, 5 \%$, and $1 \%$.

restraint to the management, and establish an effective system of separation of powers, so that enterprises can survive and develop better. On the contrary, a combination of the two will lead to an excessive concentration of power, and the main position of professionals will not be valued, which will reduce the motivation for innovation. Second, the "separation of the two positions" can overcome the limited information sources of individuals and the rigidity of cognitive models, expand the information network, and fully mobilize complementary and innovative information. This will enable companies to search for high-quality innovation projects with greater probability and gain more government support. In addition, if the Chairman serves as the General Manager, it will also limit the information processing capabilities of the board, further hindering the technological innovation of the company. Third, the "separation of the two positions" can overcome the rigidness of decision-making and improve the correctness of innovation decisions, which may be more conducive to the company's innovative growth. On the contrary, concurrent management gives the management too much power, which can easily cause mistakes in decision-making due to personal mistakes or arbitrary self-seeking behaviors. Fourth, the "separation of the two positions" can be more conducive to the organization of innovative implementation resources, overcome the limited problems of the individual resource circle, make the R\&D process of the enterprise more efficient, and ultimately promote the innovation output of the enterprise.

\section{Conclusions and Recommendations}

5.1. Main Conclusions. Based on the patent application and financial data of China's GEM listed companies from 2011 to 2017 , as well as the adjustment of the " 11 th and $12^{\text {th }}$ FiveYear Plans" to encourage industry planning, this paper examined the impact of industrial policies on the innovation output of entrepreneurial enterprises. This impact was examined from three perspectives: empirical observation, theoretical induction and empirical testing, and specific research. The main conclusions are as follows:

(1) Selective industrial policies have no obvious effect on the innovation output of entrepreneurial enterprises. In contrast to the result in the literature, the effectiveness of selective industrial policies for large- and medium-sized enterprises is minimal in GEM enterprises. This implies that the effects of industrial policies on different enterprises are different.

(2) There are structural differences in the impact of government subsidies on entrepreneurial innovation: first, government subsidies have no substantial impact on the innovation output of entrepreneurial enterprises. Second, compared with nontechnical special subsidies, special subsidies for science and technology can significantly promote entrepreneurial enterprises. Innovative output levels have superior innovation targeting.

(3) FS as an important industrial policy implies that its contribution to the innovation output of entrepreneurial enterprises is very significant. As an external incentive for enterprise innovation, FS can help enterprises solve the innovation bottleneck of financing difficulties and play an active "signal" role, effectively improve the financing environment faced by enterprises, promote enterprise R\&D investment, and improve innovation output.

(4) The effect of industrial policy on the innovation output of entrepreneurial enterprises has the characteristics of contingencies. First, the intensity of $\mathrm{R} \& \mathrm{D}$ has a positive adjustment effect on industrial policy support for entrepreneurial enterprise innovation, which indicates the importance of enterprise initiatives in innovation activities. Second, the incentive effects of industrial policies on the innovation output of entrepreneurial enterprises are not significantly different between different regions with different levels of economic development. Finally, in the enterprises that separate the roles of Chairman 
and General Manager, the industrial policy plays a stronger role in promoting the innovation output of enterprises on the GEM than in the enterprises with the dual roles.

5.2. Policy Recommendations. Based on the above research conclusions, this paper summarizes the following policy recommendations:

First, when implementing the national innovationdriven development strategy, governments at all levels should carefully evaluate the different impacts of selective industrial policies on large enterprises and SMEs and adopt different combinations of policy means based on the actual conditions of enterprises. In this study, we found that the beneficial effects of selective industrial policies are more favorable for large enterprises, but not necessarily applicable to startups.

Second, the impact of government subsidies on SMEs is very important, but this has a wide scope for self-criticism, which is likely to induce more rent-seeking activities and corruption, thus leading to a waste of resources and unhealthy tendencies. Therefore, the government should maintain the market mechanism, reduce direct intervention, and continue to optimize the incentive system of government subsidies to promote SMEs' innovation.

Third, FS is a very important means of industrial policy for SMEs. The government should deepen the reform of finance and other fields, gradually alleviate and eliminate the discrimination and "reluctance to lend" behaviors encountered by start-up enterprises in credit and financing, promote the integration of science and technology, finance, and the transformation of technological achievements, and earnestly build an FS system conducive to the innovation of SMEs.

Fourth, R\&D intensity plays an important role in the implementation of industrial policies. Therefore, to ensure that industrial policy can effectively promote the innovation output of enterprises, an effective identification mechanism requires the government to build an effective identification mechanism around the R\&D intensity of enterprises. This can not only reduce the risk of enterprise innovation activities but also help solve the problem of information asymmetry, improve the pertinence of industrial policies, and promote enterprise innovation.

Fifth, the leadership structure of entrepreneurial enterprises has an important impact on the effectiveness of industrial policies. The government should actively advocate SMEs to optimize their internal leadership structures and establish a property- rights system that is more conducive to the improvement of enterprise innovation. It is necessary to deepen cooperation among various forces of "official enterprises, universities, and research institutes," actively mobilize various social resources, maintain fair competition in the market, avoid market discrimination against SMEs in terms of opportunities and resources, realize the industrialization and commercialization of the research results of research institutions and universities, and promote resource sharing.

\section{Data Availability}

Data for prefecture level provinces in China used to support the results of this study have been published in the China Statistical Yearbook of Science and Technology (2006-2016) and China Statistical Yearbook (2006-2016) published by the National Bureau of Statistics of China. The data can be downloaded from the National Bureau of Statistics website.

\section{Conflicts of Interest}

The authors declare no conflicts of interest.

\section{Authors' Contributions}

All the authors contributed extensively to the work presented in this paper. F. W. contributed to conceptualization, project administration, methodology, and prepared the original draft. D. Z. provided software and reviewed and edited the manuscript. All authors have read and approved the final manuscript.

\section{Acknowledgments}

This work was supported by the Major Program of the Chinese National Social Science Foundation (Grant no. 21ZDA011).

\section{References}

[1] W. J. Li and M. N. Zheng, "Substantial innovation or strategic innovation: the impact of macro-industrial policies on microenterprise innovation," Economic Research, vol. 4, pp. 60-73, 2016.

[2] Y. F. Lin, "Industrial policy and China's economic development: a perspective of new structural economics," Journal of Fudan University, vol. 59, no. 02, pp. 148-153, 2017.

[3] F. Fan, H. Lian, and S. Wang, "Can regional collaborative innovation improve innovation efficiency? An empirical study of Chinese cities," Growth and Change, vol. 51, no. 1, pp. 440-463, 2020.

[4] F. Fan, S. Dai, K. Zhang, and H. Ke, "Innovation agglomeration and urban hierarchy: evidence from Chinese cities," Applied Economics, vol. 53, pp. 1-19, 2021.

[5] S. B. Choi, S. H. Lee, and C. Williams, "Ownership and firm innovation in a transition economy: evidence from China," Research Policy, vol. 40, no. 3, pp. 441-452, 2011.

[6] S. Zhang, P. Andrews-Speed, and X. Zhao, "Political and institutional analysis of the successes and failures of China's wind power policy," Energy Policy, vol. 56, pp. 331-340, 2013.

[7] F. Yu, "Government R \& D subsidies, political relations and technological SMEs innovation transformation," iBusiness, vol. 5, no. 3, p. 104, 2013.

[8] J. T. Scott, Firm versus Industry Variability in R\&D Intensity, pp. 233-248, University of Chicago Press, Chicago, IL, USA, 2007.

[9] X. Liu, X. Li, and H. Li, "R\&D subsidies and business R\&D: evidence from high-tech manufacturing firms in Jiangsu," China Economic Review, vol. 41, pp. 1-22, 2016.

[10] Z. Jin, Y. Shang, and J. Xu, "The impact of government subsidies on private R\&D and firm performance: does ownership matter in China's manufacturing industry?" Sustainability, vol. 10, no. 7, p. 2205, 2018. 
[11] J. Xu, X. Wang, and F. Liu, "Government subsidies, R\&D investment and innovation performance: analysis from pharmaceutical sector in China," Technology Analysis \& Strategic Management, vol. 33, no. 5, pp. 535-553, 2021.

[12] F. Fan, H. Lian, and X. Liu, "Can environmental regulation promote urban green innovation efficiency? An empirical study based on Chinese cities," Journal of Cleaner Production, vol. 287, Article ID 125060, 2021.

[13] F. Fan and X. Zhang, "Transformation effect of resource-based cities based on PSM-DID model: an empirical analysis from China," Environmental Impact Assessment Review, vol. 91, Article ID 106648, 2021.

[14] J. Bound, C. Cummins, and Z. Griliches, Who Does ReD and Who Patents, University of Chicago Press, Chicago, IL, USA, 2007.

[15] B. H. Hall, "The financing of research and development," Oxford Review of Economic Policy, vol. 18, no. 1, pp. 35-51, 2002.

[16] L. A. Hall and S. Bagchi-Sen, "A study of R\&D, innovation and business performance in the Canadian biotechnology industry," Technovation, vol. 22, no. 4, pp. 231-244, 2002.

[17] J. Wang, "Empirical study on the impact of R\&D subsidy on enterprise R\&D input and innovation output," Science of Science Research, vol. 9, pp. 1368-1374, 2010.

[18] W. A. Li, H. B. Li, and H. C. Li, "Innovation incentives or tax shields?-research on tax incentives for high-tech enterprises," Research Management, vol. 37, no. 11, pp. 61-70, 2016.

[19] P. Benito, "Choosing among alternative technological strategies: an empirical analysis of formal sources of innovation," Rersearch Policy, vol. 32, pp. 693-713, 2003.

[20] F. Fan and K. K. Zhang, "Decoupling analysis and rebound effect between China's urban innovation capability and resource consumption," Technology Analysis \& Strategic Management, 2021.

[21] C. Z. Sun, X. D. Yan, and L. S. Zhao, "Coupling efficiency measurement and spatial correlation characteristic of water-energy-food nexus in China," Resources, Conservation \& Recycling, vol. 164, pp. 1-11, 2021.

[22] S. Wang, M. Y. Jia, and Y. H. Zhou, "Impacts of changing urban form on ecological efficiency in China: a comparison between urban agglomerations and administrative areas," Journal of Environmental Planning and Management, vol. 63, no. 10, pp. 1834-1856, 2020.

[23] M. G. Yu, R. Fan, and H. J. Zhong, "China's industrial policy and enterprise technology innovation," China Industrial Economy, vol. 12, pp. 5-22, 2016.

[24] Q. Y. Zhu, C. Z. Sun, and L. S. Zhao, "Effect of the marine system on the pressure of the food-energy-water nexus in the coastal regions of China," Journal of Cleaner Production, vol. 319, pp. 1-12, 2021.

[25] S. Capitalism, Socialism and Democracy, The Commercial Press, Beijing, China, 1999.

[26] H. Q. Ke and S. Z. Dai, "Does innovation efficiency inhibit the ecological footprint? An empirical study of China's provincial regions," Technology Analysis \& Strategic Management, 2021.

[27] Z. F. Li and M. S. Zhang, "Research on the impact of government science and technology project input on enterprise innovation performance: data from 95 innovative enterprises in China," China Soft Science, vol. 12, pp. 123-132, 2012.

[28] H. C. Yu, J. Q. Zhang, and M. Q. Zhang, "Cross-national knowledge transfer, absorptive capacity, and total factor productivity: the intermediary effect test of international technology spillover," Technology Analysis \& Strategic Management, 2021.
[29] L. Q. Li, "Research on the effectiveness of current R\&D tax preferential policies in China," China Soft Science, vol. 7, pp. 115-119, 2007.

[30] J. Qin, "Research on financial support system for independent innovation of SMEs in science and technology," Research Management, vol. 32, no. 1, pp. 79-88, 2011.

[31] N. Liu and F. Fan, "Threshold effect of international technology spillovers on China's regional economic growth," Technology Analysis \& Strategic Management, vol. 32, no. 8, pp. 923-935, 2020.

[32] S. Wang and J. Q. Zhang, "The symbiosis of scientific and technological innovation efficiency and economic efficiency in China - an analysis based on data envelopment analysis and logistic model," Technology Analysis \& Strategic Management, vol. 31, no. 1, pp. 67-80, 2019.

[33] J. Zhang, D. B. Gao, and Y. L. Xia, "Whether patents can promote China's economic growth: an explanation based on the perspective of Chinese patent subsidy policy," China Industrial Economy, vol. 1, pp. 83-98, 2016.

[34] P. Aghion, J. Cai, and M. Dewatripont, "Industrial policy and competition," Social Science Electronic Publishing, vol. 7, no. 4, pp. 1-32, 2015.

[35] S. Wang and X. L. Wang, "The impact of collaborative innovation on ecological efficiency-empirical research based on China's regions," Technology Analysis \& Strategic Management, vol. 33, no. 2, pp. 242-256, 2021.

[36] J. Jiang, "Performance of public policy support for enterprise innovation: a comparative analysis based on direct subsidy and tax preference," Science Research Management, vol. 32, no. 4, pp. 1-8, 2011.

[37] X. L. Wang, L. Wang, and S. Wang, "Marketisation as a channel of international technology diffusion and green total factor productivity: research on the spillover effect from China's first-tier cities," Technology Analysis \& Strategic Management, vol. 33, no. 5, pp. 491-504, 2021.

[38] B. O. Benat and R. P. Andres, "From R\&D to innovation and economic growth in the EU," Growth and Change, vol. 4, pp. 434-455, 2004.

[39] Y. M. Guo, "An empirical study on the influencing factors of enterprise innovation performance," Journal of Hebei University of Technology, vol. 43, no. 1, pp. 101-106, 2014.

[40] J. X. Hao and Z. Yang, "Analysis of the influence of regional factors on the innovation performance of entrepreneurial enterprises-_based on the statistical data of venture enterprises in 52 cities in China," Jiangsu Social Sciences, no. 6, pp. 84-89, 2012.

[41] S. H. Kong, "An empirical analysis of the role of tax preferentials in promoting science and technology innovation: an empirical analysis based on provincial panel data," Science \& Technology Progress and Policy, vol. 27, no. 24, pp. 32-36, 2010.

[42] Y. Peng, "Research on agency problem in China's GEM corporate governance," Accounting News, vol. 20, pp. 25-26, 2011.

[43] S. A. Zahra, D. O. Neubaum, and M. Huse, "Entrepreneurship in medium-size companies: exploring the effects of ownership and governances systems," Journal of Management, vol. 26, no. 5, pp. 947-976, 2000.

[44] L. Wang, "Relationship-specific investment and technological innovation performance under the role of VC governance behavior," Journal of Management, vol. 12, no. 6, p. 854, 2015.

[45] J. F. Xu and W. Liu, "Corporate governance structure and technology innovation," Research Management, no. 4, pp. 11-15, 2002. 
[46] J. A. Brickley, J. L. Coles, and G. A. Jarrell, "Leadership structure: separating the CEO and chairman of the board," Journal of Corporate Finance, vol. 4, pp. 189-220, 1997.

[47] J. Cornaggia, Y. Mao, X. Tian, and B. Wolfe, "Does banking competition affect innovation," Journal of Financial Economics, vol. 115, no. 1, pp. 189-209, 2015.

[48] C. Lin, P. Lin, and F. M. Song, "Managerial incentives, CEO characteristics and corporate innovation in China's private sector," Journal of Comparative Economics, vol. 39, no. 2, pp. 176-190, 2011. 